\title{
REVIEW
}

\section{ELECTIVE CESAREAN SECTION ON MATERNAL REQUEST WITHOUT INDICATION: REASONS FOR IT, AND ITS ADVANTAGES AND DISADVANTAGES}

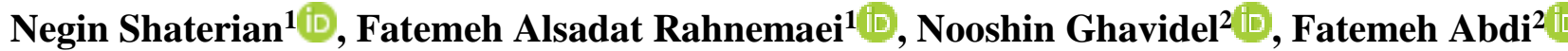 \\ ${ }^{1}$ Student Research Committee, School of Nursing and Midwifery, Shahid Beheshti University of Medical Sciences, Tehran, Iran \\ ${ }^{2}$ Social Determinants of Health Research Center, Alborz University of Medical Sciences, Karaj, Iran
}

Received May 5, 2020; Accepted August 7, 2020. Copyright: This is an open access article under the CC BY-NC-ND license.

\begin{abstract}
Aim: The aim of this study was to analyze the available research evidence on the reasons for, and advantages and disadvantages of elective cesarean section on maternal request. Design: Literature review. Methods: The review was conducted using Web of Science, PubMed, Embase, Scopus, ProQuest, and Google Scholar from 2009 to 2020, based on PRISMA guidelines, and Mesh keywords. All types of studies reporting on the subject of the research were included, excepting case reports. STROBE and JBI checklists were used to assess the quality of studies. Sixteen studies were included in this literature review. Results: Fear of complications during vaginal delivery was the most frequent maternal reason for elective cesarean section. Fear of physical injury to the infant during vaginal delivery was the most frequent neonatal reason for elective cesarean section. Birth experiences of family, friends, or relatives was the most frequent social maternal reason given for elective cesarean section. The most common advantage of cesarean section was reduction in neonatal injuries. The incidence of maternal wound infection and risk of neonatal respiratory distress syndrome were the most common disadvantages of cesarean section. Conclusion: Identifying the reasons for cesarean section on maternal request can help create a more precise roadmap for increasing awareness in women of the advantages of vaginal delivery, preventing prenatal complications, and reducing costs in healthcare systems.
\end{abstract}

Keywords: advantages, cesarean section, disadvantages, maternal request, reasons, vaginal delivery.

\section{Introduction}

Vaginal delivery (VD) is a natural process and has traditionally been considered the primary mode of delivery worldwide (Carter, 2016). It is a spontaneous process that usually requires no medical intervention, and cesarean section (CS) is only performed if $\mathrm{VD}$ is contraindicated in order to maintain the health of the mother and newborn baby (Navaee \& Abedian, 2015). The phenomenon of increasing CS rates has been registered in most countries worldwide (Câmara et al., 2016). Cesarean section on maternal request (CSMR) can be described as a CS requested by the mother, without obstetric or medical indications (Sharpe et al., 2015). CSMR is comparatively rare in the United Kingdom (1-2\% of births) and the USA (3\% of births), but in some middle income countries the rate is high and increasing (20\% of births in southeastern China), making it a worldwide public health concern (Blustein \& Liu, 2015). A maternal request for CS without maternal or fetal indication may increase

Corresponding author: Fatemeh Abdi, Social Determinants of Health Research Center, Alborz University of Medical Sciences, Hassan Abad, Karaj, Iran; email: abdi@sbmu.ac.ir risk-benefit considerations and ethical concerns for a healthcare provider (Alsayegh et al., 2018). Fear of $\mathrm{VD}$ is the most frequent reason given for CS, but generally, women giving birth by CSMR are older, more often use tobacco products, exhibit a lower educational level, have greater body mass index (BMI), are unemployed, and their parents were more often born outside of Scandinavia (Sydsjö et al., 2015). A study carried out in Norway also showed that anxiety, depression, low self-esteem, history of childhood sexual abuse, and low level of satisfaction in relationship with partner are associated with a preference for CS (Kringeland et al., 2009). Other reasons for maternal requests for CS are recommendations from healthcare professionals, experiences and recommendations from relatives and friends, negative accounts of a specific mode, which increases anxiety in mothers of having a similar experience during labor (Loke et al., 2015) poor mental health, and poor social support (Olieman et al., 2017).

Cesarean section is a surgical procedure that can lead to several complications in both the mother and the baby (Mylonas \& Friese, 2015). Possible risks of CS 
by maternal request include longer duration of hospital stay, increased risk of respiratory problems in the baby, and increased risk of complications in subsequent pregnancies, such as uterine rupture, placental implantation problems, and need of hysterectomy (American College of Obstetricians and Gynecologists, 2013). The benefits of CS can include: 1) avoidance of prolonged labor; 2) avoidance of labor pain; 3) reduction in fear of overlong labor and fetal injuries; and 4) quicker and more convenient manner of delivery (Loke et al., 2015). Today, approximately $2.5 \%-18 \%$ of CSs are performed without medical indication worldwide. It is estimated that $10 \%-20 \%$ of all deliveries in northern Europe, the United States, Sweden, and Australia are CSs on maternal request (Gao et al., 2019). In Iran, 47\% of deliveries are terminated by CS, of which $40 \%$ are performed at the mother's request (Zamani-Alavijeh et al., 2018).

Since VD is the best method of delivery for mothers who are healthy and without contraindications, and the number of CSMR without obstetrical or medical indications is increasing annually - despite the fact that CS has many risks for both mother and baby during and after delivery, the purpose of this study was to systematically review the literature regarding the reasons for elective CS on maternal request without indication, and its advantages and disadvantages.

\begin{abstract}
Aim
The aim of this study was to analyze the available research evidence on the reasons for, and advantages and disadvantages of elective cesarean section on maternal request.
\end{abstract}

\section{Methods}

\section{Design}

Literature review.

This study was reported according to Preferred Reporting Items for Systematic Reviews and MetaAnalyses (PRISMA) guidelines (Rahnemaie et al., 2019).

\section{Eligibility criteria}

Inclusion criteria were: all studies in Persian and English published between 2009-2020, using the Medical Subject Headings (Mesh) terms including: "cesarean section" [tiab] OR "CS" OR "C-Section" [tiab] OR "elective cesarean section" [tiab] OR "elective CS" OR "cesarean delivery" [tiab] OR "elective cesarean delivery" [tiab] OR "abdominal delivery" [tiab] and "maternal request" [tiab] and "advantage" [tiab], OR "advantages" [tiab] OR "disadvantage" [tiab], OR "disadvantages" [tiab] and "reason" [tiab] OR "reasons" searched for in the databases. Studies examining healthy pregnant women requesting CS and women electing to have a caesarean section were included in the study.

Studies were excluded according to the following criteria:

- reviews, case reports, comments, and letters;

- studies focusing on babies in the breech position;

- studies investigating pregnant women with underlying diseases;

- studies examining emergency caesarean sections.

\section{Search Strategy}

The Web of Science, PubMed, Embase, Scopus, ProQuest, and Google Scholar databases were systematically searched for relevant studies published between 2009 and 2020. Quantitative and qualitative studies were included if they met certain inclusion criteria and did not match any of the exclusion criteria.

\section{Study Selection inc. PRISMA flow diagram}

The initial search yielded 2,170 results. All studies were independently assessed for eligibility by two authors and any disagreements were resolved by consensus. After initial screening, 1,085 irrelevant or duplicated studies were excluded. A further 951 papers were excluded after reviewing the titles and abstracts. Of the remaining 134 full-text articles, 118 were excluded due to ineligibility. Finally, a total of 16 eligible articles met our inclusion criteria and were included in the review (Figure 1).

\section{Evaluation of quality of articles}

The STROBE statement was applied to assess the quality of quantitative studies (Abdi et al., 2019). The checklist items focus on reporting how trials were designed, analyzed and interpreted. An authoritative tool, the STROBE Statement includes a checklist of 22 items. The checklist items focus on the reporting or assessment of different sections of observational studies. The Joanna Briggs Institute (JBI) checklist was used to evaluate qualitative studies. Both STROBE Statement and JBI checklists were used to assess the quality of mixed method studies.

\section{Data extraction}

Two investigators independently searched for relevant scientific publications, carried out validity assessments, and resolved any disagreements by consulting a third investigator. The methodological quality of the studies was assessed by author name, year of publication, study design, country, sample size, maternal age, data collection, advantages, disadvantages, social reasons, individual reasons, and quality score. 


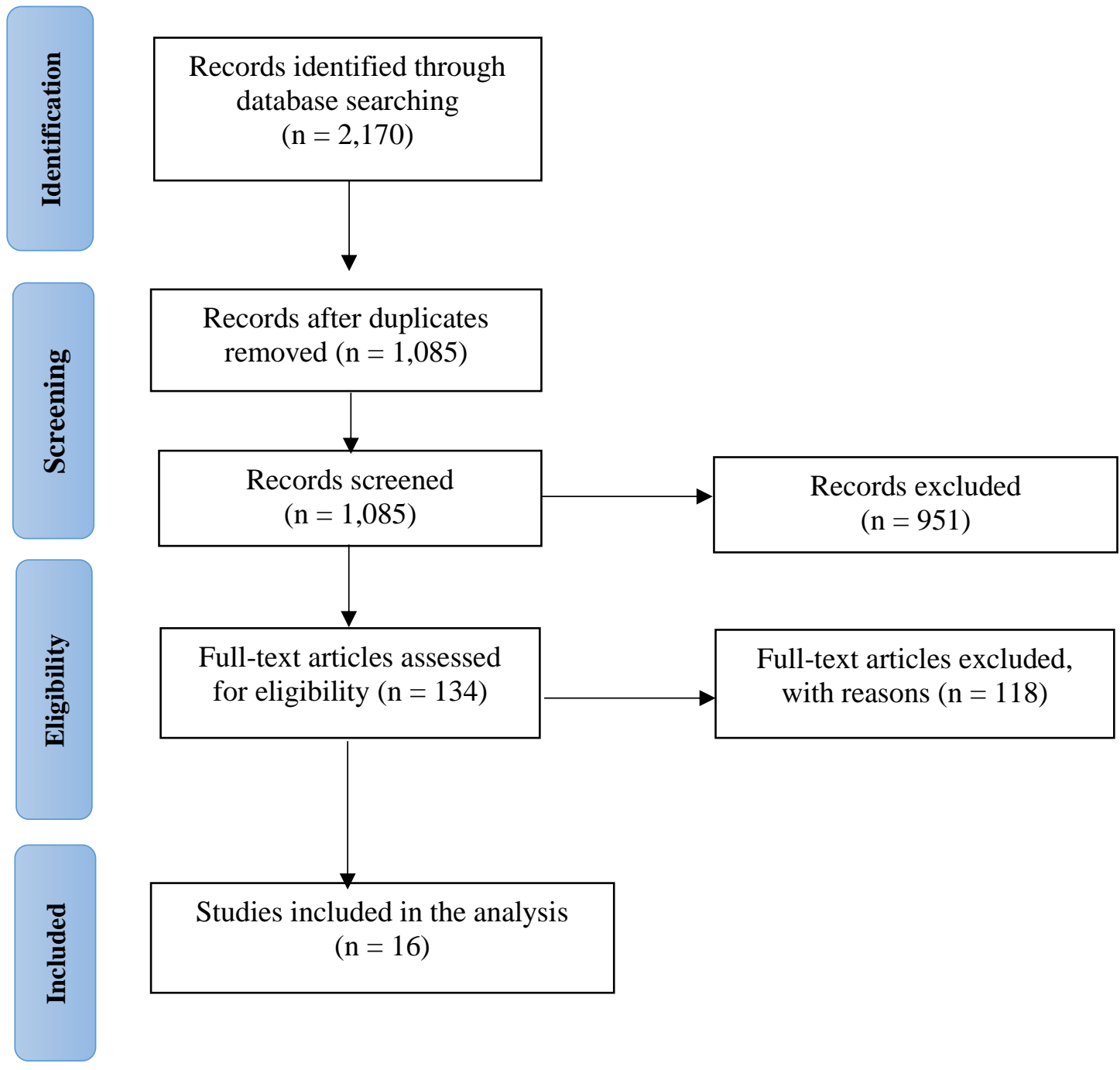

Figure 1 PRISMA Flow diagram

\section{Results}

After evaluation of the articles, only 16 were finally deemed eligible for inclusion in this systematic review, of which three were qualitative studies, 12 were quantitative studies, and one study was of mixed methodology. 16 studies were conducted in the following countries: China (3 studies), the United Kingdom (3 studies), Sweden (2 studies), Nigeria (2 studies), Iran (4 studies), Israel (1 study), Austria (1 study), Australia (1 study), Denmark (1 study), Canada (1 study), and Colombia (1 study) (Table 1).

\section{Reasons for Elective CS}

Reasons for elective CSMR can be divided into two categories: maternal indications, and fetal indications. A review of studies indicated that individual maternal factors behind elective CS included: fear of VD and its complications (8 studies), older maternal age (8 studies), attitudes toward cesarean birth on maternal request - i.e., the belief that it is safe and under control (4 studies), maternal education (4 studies), maternal obesity or BMI (3 studies), availability of options in childbirth (3 studies), maternal anxiety (2 studies), previous natural birth experience (2 studies), and having no intention of becoming pregnant again.

In addition, a single study examined the following factors: maternal self-confidence, women with larger fetuses, easier and faster labor, occupational status, all psychiatric disorders (except mental retardation), problems due to the use of psychoactive substances, fear of losing social position, type of health facility, more frequent use of tobacco products, previous pregnancy losses, a history of infertility, difficulties in conception, and women more likely to have been born outside of Sweden.

Social maternal factors behind elective CS included family, relatives, and friends or neighbors (4 studies), advice from healthcare professionals, friends, 
Table 1 Characteristics of included studies

\begin{tabular}{|c|c|c|c|c|c|c|c|}
\hline Author (Year) & $\begin{array}{l}\text { Study } \\
\text { design }\end{array}$ & Country & Para & $\begin{array}{l}\text { Sample } \\
\text { size }\end{array}$ & $\begin{array}{l}\text { Maternal } \\
\text { age (years) }\end{array}$ & Data collection & $\begin{array}{l}\text { Quality } \\
\text { score }\end{array}$ \\
\hline $\begin{array}{l}\text { Gao et al. } \\
(2019)\end{array}$ & $\begin{array}{l}\text { cross- } \\
\text { sectional }\end{array}$ & China & $\begin{array}{l}\text { primipara } \\
\text { and } \\
\text { multipara }\end{array}$ & 564 & $23-48$ & Voluntary questionnaire & $18^{\mathrm{a}}$ \\
\hline $\begin{array}{l}\text { Otkjaer et al. } \\
(2019)\end{array}$ & cohort & Denmark & $\mathrm{NR}^{\mathrm{c}}$ & 145,821 & $\begin{array}{l}\text { all age } \\
\text { ranges }\end{array}$ & Danish coding system & $21^{\mathrm{a}}$ \\
\hline $\begin{array}{l}\text { Zamani- } \\
\text { Alavijeh et al. } \\
(\mathbf{2 0 1 8 )}\end{array}$ & $\begin{array}{l}\text { cross- } \\
\text { sectional }\end{array}$ & Iran & $\begin{array}{l}\text { primipara } \\
\text { and } \\
\text { multipara }\end{array}$ & 200 & $15-44$ & $\begin{array}{l}\text { Interviews and eight-part } \\
\text { questionnaire }\end{array}$ & $19^{\mathrm{a}}$ \\
\hline $\begin{array}{l}\text { Liu et al. } \\
(2015)\end{array}$ & cohort & China & NR & 66,226 & $\begin{array}{l}\text { all age } \\
\text { ranges }\end{array}$ & $\begin{array}{l}\text { Hospital electronic medical } \\
\text { record according to criteria set } \\
\text { down on the standardized data } \\
\text { collection form }\end{array}$ & $21^{\mathrm{a}}$ \\
\hline $\begin{array}{l}\text { Loke et al. } \\
(2015)\end{array}$ & $\begin{array}{l}\text { cross- } \\
\text { sectional }\end{array}$ & China & NR & 319 & $18-45$ & Self-administered questionnaire & $20^{\mathrm{a}}$ \\
\hline $\begin{array}{l}\text { Sharpe et al. } \\
(2015)\end{array}$ & $\begin{array}{l}\text { cross- } \\
\text { sectional }\end{array}$ & $\begin{array}{l}\text { United } \\
\text { Kingdom }\end{array}$ & $\begin{array}{l}\text { primipara } \\
\text { and } \\
\text { multipara }\end{array}$ & 249 & $15-43$ & Pilot questionnaire & $15^{\mathrm{a}}$ \\
\hline $\begin{array}{l}\text { Sydsjö et al. } \\
(2015)\end{array}$ & cohort & Sweden & $\begin{array}{l}\text { primipara } \\
\text { and } \\
\text { multipara }\end{array}$ & 64,834 & $\begin{array}{l}\text { all age } \\
\text { ranges }\end{array}$ & Swedish medical birth register & $18^{\mathrm{a}}$ \\
\hline $\begin{array}{l}\text { Akintayo et } \\
\text { al. (2014) }\end{array}$ & $\begin{array}{l}\text { cross- } \\
\text { sectional }\end{array}$ & Nigeria & NR & 753 & $\begin{array}{l}\text { all age } \\
\text { ranges }\end{array}$ & $\begin{array}{l}\text { Self-administered semi- } \\
\text { structured questionnaire }\end{array}$ & $17^{\mathrm{a}}$ \\
\hline $\begin{array}{l}\text { Miller et al. } \\
(2013)\end{array}$ & $\begin{array}{l}\text { decision } \\
\text { analytic } \\
\text { model }\end{array}$ & California & $\begin{array}{l}\text { primipara } \\
\text { and } \\
\text { multipara }\end{array}$ & 1,000 & NR & $\begin{array}{l}\text { Two different approaches a } \\
\text { nulliparous woman could use for } \\
\text { her first delivery: trial of labor } \\
\text { or elective CS }\end{array}$ & $17^{\mathrm{b}}$ \\
\hline $\begin{array}{l}\text { Okonkwo et al } \\
(2012)\end{array}$ & $\begin{array}{l}\text { cross- } \\
\text { sectional }\end{array}$ & Nigeria & $\begin{array}{l}\text { primipara } \\
\text { and } \\
\text { multipara }\end{array}$ & 843 & $\begin{array}{l}\text { all age } \\
\text { ranges }\end{array}$ & $\begin{array}{l}\text { A } 33 \text {-item questionnaire was } \\
\text { generated from previous } \\
\text { surveys, publications, and } \\
\text { review articles on MDCS }\end{array}$ & $17^{\mathrm{a}}$ \\
\hline $\begin{array}{l}\text { Handelzalts et } \\
\text { al. (2011) }\end{array}$ & $\begin{array}{l}\text { cross- } \\
\text { sectional }\end{array}$ & Israel & primipara & 59 & $22-39$ & Interview and questionnaire & $18^{\mathrm{a}}$ \\
\hline $\begin{array}{l}\text { Bodner et al. } \\
(2011)\end{array}$ & $\begin{array}{l}\text { cross- } \\
\text { sectional }\end{array}$ & Austria & $\begin{array}{l}\text { primipara } \\
\text { and } \\
\text { multipara }\end{array}$ & 178 & $19-45$ & $\begin{array}{l}\text { Data recorded from Department } \\
\text { of Obstetrics and Gynecology at } \\
\text { the Rudolfstiftung Hospital }\end{array}$ & $17^{\mathrm{a}}$ \\
\hline $\begin{array}{l}\text { Karlström et } \\
\text { al. (2011) }\end{array}$ & cohort & Sweden & $\begin{array}{l}\text { primipara } \\
\text { and } \\
\text { multipara }\end{array}$ & 693 & $\begin{array}{l}\text { All age } \\
\text { ranges }\end{array}$ & Questionnaire & $14^{\mathrm{a}}$ \\
\hline $\begin{array}{l}\text { Fenwick et al. } \\
(\mathbf{2 0 1 0})\end{array}$ & qualitative & Australia & primipara & 210 & $27-39$ & Interview & $18^{\mathrm{b}}$ \\
\hline $\begin{array}{l}\text { Kingdon et al. } \\
(2009)\end{array}$ & $\begin{array}{l}\text { mixed } \\
\text { methods }\end{array}$ & $\begin{array}{l}\text { United } \\
\text { Kingdom }\end{array}$ & primipara & 454 & $<45$ & Questionnaires and interviews & $18^{\mathrm{b}}$ \\
\hline $\begin{array}{l}\text { Munro et al. } \\
(2009)\end{array}$ & qualitative & $\begin{array}{l}\text { United } \\
\text { Kingdom, } \\
\text { Colombia, } \\
\text { Canada }\end{array}$ & primipara & 17 & NR & Interview & $17^{\mathrm{b}}$ \\
\hline
\end{tabular}


relatives (2 studies), others fueling mothers' doubts about type of delivery and fears regarding labor and $\mathrm{VD}$, sense of trust in doctors, residential status, male obstetrician, role of mass media - including books, internet sources, and television programs about childbirth, fundamental issues with labor and delivery, absence of support during labor (2 studies), and absence of general and social support for women.

Neonatal reasons for CSMR were as follows: fear of physical injury to baby or otherwise endangering the health of the baby by VD (6 studies), secondhand accounts of VD from other women, and having control over the date of childbirth.

\section{Advantages of elective CS}

Maternal reasons for elective CS were as follows: reduced fear of childbirth and neonatal complications (3 studies), preservation of sexual function and genital appearance and minimization of potential sexual dissatisfaction (3 studies), safe procedure of delivery (2 studies), faster and easier method of delivery (1 study), avoidance of labor pain (1 study), avoidance of the necessity of induced labor, avoidance of pain from repetitive vaginal examinations, fashionable / modern manner of delivery, possibility of tubal ligation after CS, greater ability to plan maternity leave, possibility to select an auspicious date for delivery of the baby, avoidance of pelvic floor disorders, and a higher level of control over the birth.
Neonatal reasons for CSMR included decrease in morbidity rate and neonatal mortality caused by VD (2 studies), reduced likelihood of experiencing complications with mild primary pulmonary hypertension (PPH) and lower incidence of birth trauma (Table 2).

\section{Disadvantages of elective CS}

Maternal disincentives for elective CS were as follows: increased risk of wound infection (4 studies), prolonged hospital stay (2 studies), bleeding (2 studies), bladder injury, ureteral injury and intestinal injury, higher risks of maternal morbidity and mortality, significant increases in the use of iron supplementation due to medical analgesics and antibiotics, problems with breastfeeding, a considerably higher rate of puerperal febrile morbidity, a more negative birth experience, higher level of anesthetic blocks, epidural complications, severe vomiting, and sense of anticlimax, due to the brevity of labor (Table 3 ).

Neonatal disincentives for elective CS included: higher risk of respiratory distress syndrome (2 studies), low birth weight, temporary facial nerve injury, intraventricular hemorrhage, increased risk of neonatal intensive care unit (NICU) admission, neonatal infection, hypoxic ischemic encephalopathy, and meconium aspiration process (each of which were investigated in a single study) (Table 4).

Table 2 Maternal reasons for choice of an elective CS without indication (Part 1)

\begin{tabular}{|c|c|c|c|c|c|}
\hline Author (Year) & Individual reasons & p-value & Social reasons & p-value & Results \\
\hline \multirow[t]{2}{*}{ Gao et al. (2019) } & advanced maternal age & 0.080 & \multirow[t]{2}{*}{ residential status } & \multirow[t]{2}{*}{0.009} & \multirow[t]{2}{*}{$\begin{array}{l}\text { The reasons given could affect the rate o } \\
\text { CS on maternal request. }\end{array}$} \\
\hline & $\begin{array}{l}\text { attendance of a prenatal } \\
\text { education course }\end{array}$ & 0.045 & & & \\
\hline $\begin{array}{l}\text { Otkjaer et al. } \\
\text { (2019) }\end{array}$ & $\begin{array}{l}\text { advanced maternal age } \\
\text { more often overweight } \\
\text { more often smokers }\end{array}$ & $\begin{array}{c}<0.0001 \\
<0.0001 \\
0.020\end{array}$ & NR & NR & \multirow{2}{*}{$\begin{array}{l}\text { No increased risk of major maternal } \\
\text { complications associated with PCD. All } \\
\text { major complications occurred in women } \\
\text { with PVD, but the occurrence was so } \\
\text { infrequent that no significant difference } \\
\text { was found. } \\
\text { Attitude and self-efficacy had a greater } \\
\text { predictive power for selection of delivery } \\
\text { mode. }\end{array}$} \\
\hline $\begin{array}{l}\text { Zamani-Alavijeh } \\
\text { et al. (2018) }\end{array}$ & $\begin{array}{l}\text { self-efficacy } \\
\text { attitude }\end{array}$ & $\begin{array}{c}0.002 \\
<0.001\end{array}$ & $\begin{array}{l}\text { general social } \\
\text { support }\end{array}$ & 0.780 & \\
\hline \multirow[t]{3}{*}{ Liu et al. (2015) } & $\begin{array}{l}\text { advanced maternal age } \\
\text { overweight or obese } \\
\text { women }\end{array}$ & $\begin{array}{l}<0.001 \\
<0.001\end{array}$ & \multirow[t]{3}{*}{ NR } & \multirow[t]{3}{*}{ NR } & \multirow{3}{*}{$\begin{array}{l}\text { There is no significant difference } \\
\text { between the CSMR and PVD groups in } \\
\text { the frequencies of maternal intensive } \\
\text { care unit admission, severe postpartum } \\
\text { hemorrhage, maternal infection, organ } \\
\text { injuries, thromboembolic disorders, } \\
\text { perinatal mortality rate. The frequency of } \\
\text { respiratory-distress syndrome was higher } \\
\text { in the CSMR group. }\end{array}$} \\
\hline & $\begin{array}{l}\text { women with larger } \\
\text { fetuses }\end{array}$ & $<0.001$ & & & \\
\hline & assisted pregnancy & $<0.001$ & & & \\
\hline
\end{tabular}


Table 2 Maternal reasons for choice of an elective CS without indication (Part 2)

\begin{tabular}{|c|c|c|c|c|c|}
\hline Author (Year) & Individual reasons & p-value & Social reasons & p-value & Results \\
\hline \multirow{8}{*}{$\begin{array}{l}\text { Loke et al. } \\
(2015)\end{array}$} & age & 0.008 & family history of difficulty & 0.001 & \multirow{8}{*}{$\begin{array}{l}\text { Constructs of the Health Belief } \\
\text { Model - perceived benefits, } \\
\text { perceived severity, and cues to } \\
\text { action - affect the decision that } \\
\text { women make on their mode of } \\
\text { delivery. }\end{array}$} \\
\hline & level of education & 0.016 & $\begin{array}{l}\text { advice from healthcare } \\
\text { professionals }\end{array}$ & 0.004 & \\
\hline & occupational status & 0.016 & $\begin{array}{l}\text { advice from friends / } \\
\text { relatives }\end{array}$ & $<0.001$ & \\
\hline & $\begin{array}{l}\text { maternal health } \\
\text { safer mode of birth for } \\
\text { the mother }\end{array}$ & $\begin{array}{c}<0.001 \\
\text { NR }\end{array}$ & \multirow[t]{5}{*}{$\begin{array}{l}\text { had heard negative stories } \\
\text { about VD }\end{array}$} & \multirow[t]{5}{*}{0.006} & \\
\hline & to avoid labor pain & $<0.001$ & & & \\
\hline & $\begin{array}{l}\text { certainty about the date } \\
\text { of the birth }\end{array}$ & $<0.001$ & & & \\
\hline & $\begin{array}{l}\text { to avoid prolonged } \\
\text { labor }\end{array}$ & $<0.001$ & & & \\
\hline & $\begin{array}{l}\text { fast and convenient } \\
\text { delivery }\end{array}$ & $<0.001$ & & & \\
\hline \multirow{2}{*}{$\begin{array}{l}\text { Sharpe et al. } \\
(2015)\end{array}$} & fear of childbirth & NR & \multirow[t]{2}{*}{ NR } & \multirow[t]{2}{*}{ NR } & \multirow{10}{*}{$\begin{array}{l}\text { Healthcare professionals and } \\
\text { pregnant women's views differ } \\
\text { significantly. } \\
\text { The burden of psychiatric illnesses } \\
\text { was significantly higher in women } \\
\text { giving birth by caesarean section } \\
\text { on maternal request. }\end{array}$} \\
\hline & fear of injury to self & NR & & & \\
\hline \multirow[t]{8}{*}{$\begin{array}{l}\text { Sydsjö et al. } \\
(2015)\end{array}$} & $\begin{array}{l}\text { advanced maternal age } \\
\text { more frequent use of } \\
\text { tobacco products }\end{array}$ & $\begin{array}{l}0.015 \\
<0.001\end{array}$ & \multirow[t]{8}{*}{$\begin{array}{l}\text { more often had parents born } \\
\text { outside of Scandinavia }\end{array}$} & \multirow[t]{8}{*}{$<0.001$} & \\
\hline & lower educational level & $<0.001$ & & & \\
\hline & $\begin{array}{l}\text { more frequently } \\
\text { unemployed }\end{array}$ & $<0.001$ & & & \\
\hline & higher BMI & $<0.001$ & & & \\
\hline & $\begin{array}{l}\text { all psychiatric disorders } \\
\text { except mental } \\
\text { retardation }\end{array}$ & $<0.001$ & & & \\
\hline & $\begin{array}{l}\text { complications of using } \\
\text { psychoactive } \\
\text { substances, such as: } \\
\text { neurotic disorders, } \\
\text { stress }\end{array}$ & $<0.001$ & & & \\
\hline & $\begin{array}{l}\text { disorders of adult } \\
\text { personality and } \\
\text { behavior }\end{array}$ & $<0.001$ & & & \\
\hline & $\begin{array}{l}\text { neurotic disorders, } \\
\text { stress-related disorders, } \\
\text { and somatoform } \\
\text { disorders }\end{array}$ & $<0.001$ & & & \\
\hline \multirow[t]{5}{*}{$\begin{array}{l}\text { Akintayo et al. } \\
(\mathbf{2 0 1 4 )}\end{array}$} & $\begin{array}{l}\text { fear of losing the baby } \\
\text { during labor }\end{array}$ & NR & \multirow{5}{*}{$\begin{array}{l}\text { previous experience of poor } \\
\text { attitude from health workers } \\
\text { during labor } \\
\text { lack of family support when } \\
\text { in labor }\end{array}$} & \multirow[t]{5}{*}{ NR } & \multirow{5}{*}{$\begin{array}{l}\text { The most common motivations for } \\
\text { the request were fear of losing the } \\
\text { baby during labor, delay in } \\
\text { conception, and fear of labor pains. }\end{array}$} \\
\hline & delay in conception & NR & & & \\
\hline & fear of labor pains & NR & & & \\
\hline & fear of incontinence & NR & & & \\
\hline & $\begin{array}{l}\text { unsatisfactory sexual } \\
\text { intercourse }\end{array}$ & NR & & & \\
\hline $\begin{array}{l}\text { Miller et al. } \\
(2013)\end{array}$ & NR & NR & NR & NR & $\begin{array}{l}\text { Choosing an initial CS resulted } \\
\text { in increased risk of a major } \\
\text { adverse maternal outcome in the } \\
\text { first pregnancy. The risk of an } \\
\text { adverse neonatal outcome was } \\
\text { higher among offspring of } \\
\text { women who had chosen an initial } \\
\text { elective CS. }\end{array}$ \\
\hline
\end{tabular}


Table 2 Maternal reasons for choice of an elective CS without indication (Part 3)

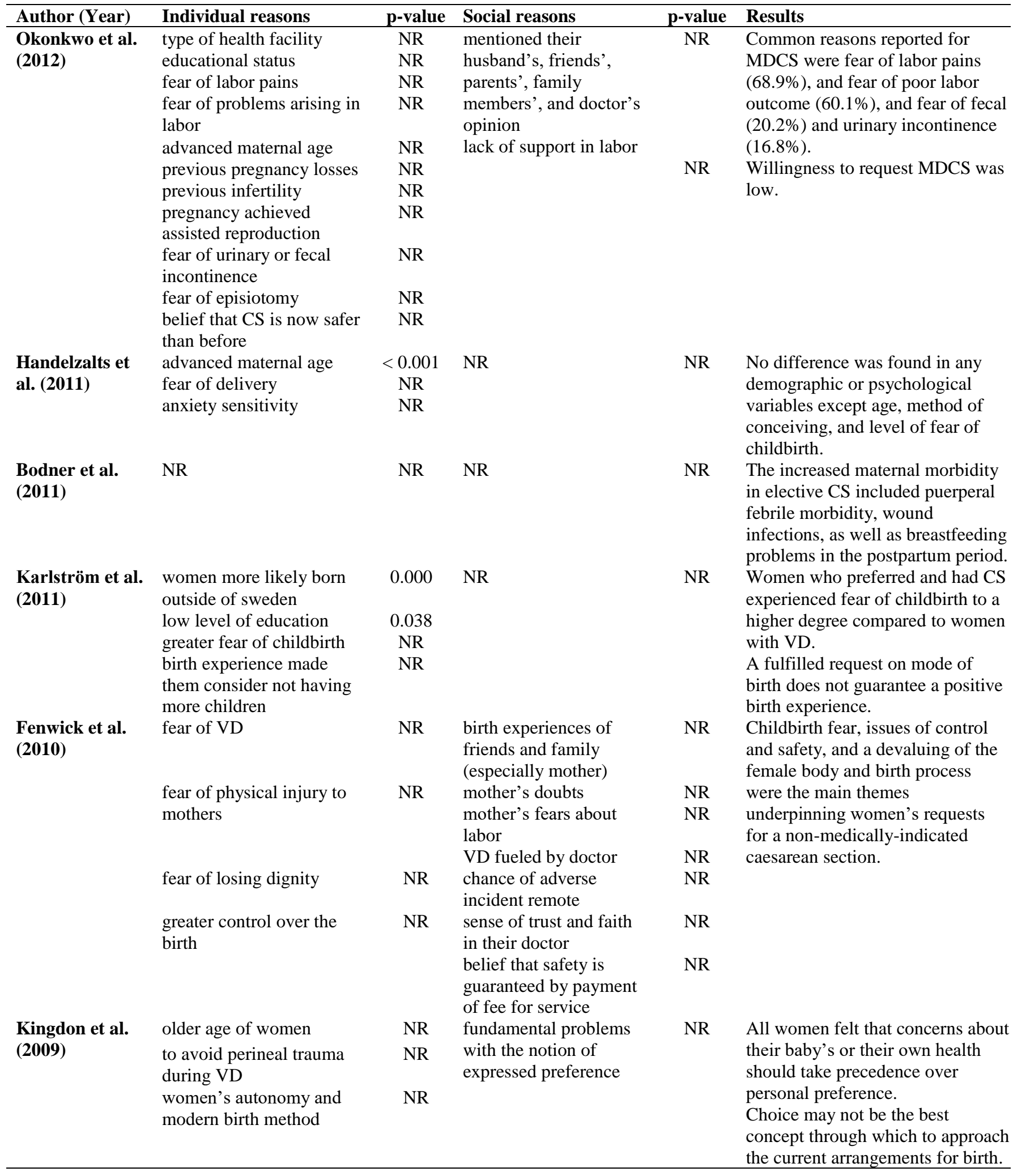


Table 2 Maternal reasons for choice of an elective CS without indication (Part 4)

\begin{tabular}{|c|c|c|c|c|c|}
\hline Author (Year) & Individual reasons & p-value & Social reasons & p-value & Results \\
\hline $\begin{array}{l}\text { Munro et al. } \\
\text { (2009) }\end{array}$ & $\begin{array}{l}\text { previous stressful, } \\
\text { traumatic, or unsatisfactory } \\
\text { birth experiences in } \\
\text { multipara } \\
\text { to avoid labor pain } \\
\text { to reduce anxiety during } \\
\text { labor } \\
\text { self-perception }\end{array}$ & $\begin{array}{l}\text { NR } \\
\text { NR } \\
\text { NR }\end{array}$ & $\begin{array}{l}\text { heard stories of VD } \\
\text { from other women } \\
\text { heard stories about the } \\
\text { length of labor } \\
\text { hinged on qualities } \\
\text { associated with } \\
\text { organization and control } \\
\text { accounts of birth in } \\
\text { books and internet } \\
\text { fear of VD due to } \\
\text { negative television } \\
\text { portrayal } \\
\text { husband's level of } \\
\text { discomfort with } \\
\text { television images of VD } \\
\text { or animals in labor } \\
\text { social, physiological, } \\
\text { historical, and practical } \\
\text { influences }\end{array}$ & $\begin{array}{l}\text { NR } \\
\text { NR } \\
\text { NR }\end{array}$ & $\begin{array}{l}\text { Social and cultural knowledge } \\
\text { formed their decision to give birth } \\
\text { by patient-initiated elective CS. } \\
\text { However, numbers of women who } \\
\text { request a cesarean delivery for } \\
\text { social reasons is still small. }\end{array}$ \\
\hline
\end{tabular}

Table 3 Advantages and disadvantages of CSMR (Part 1)

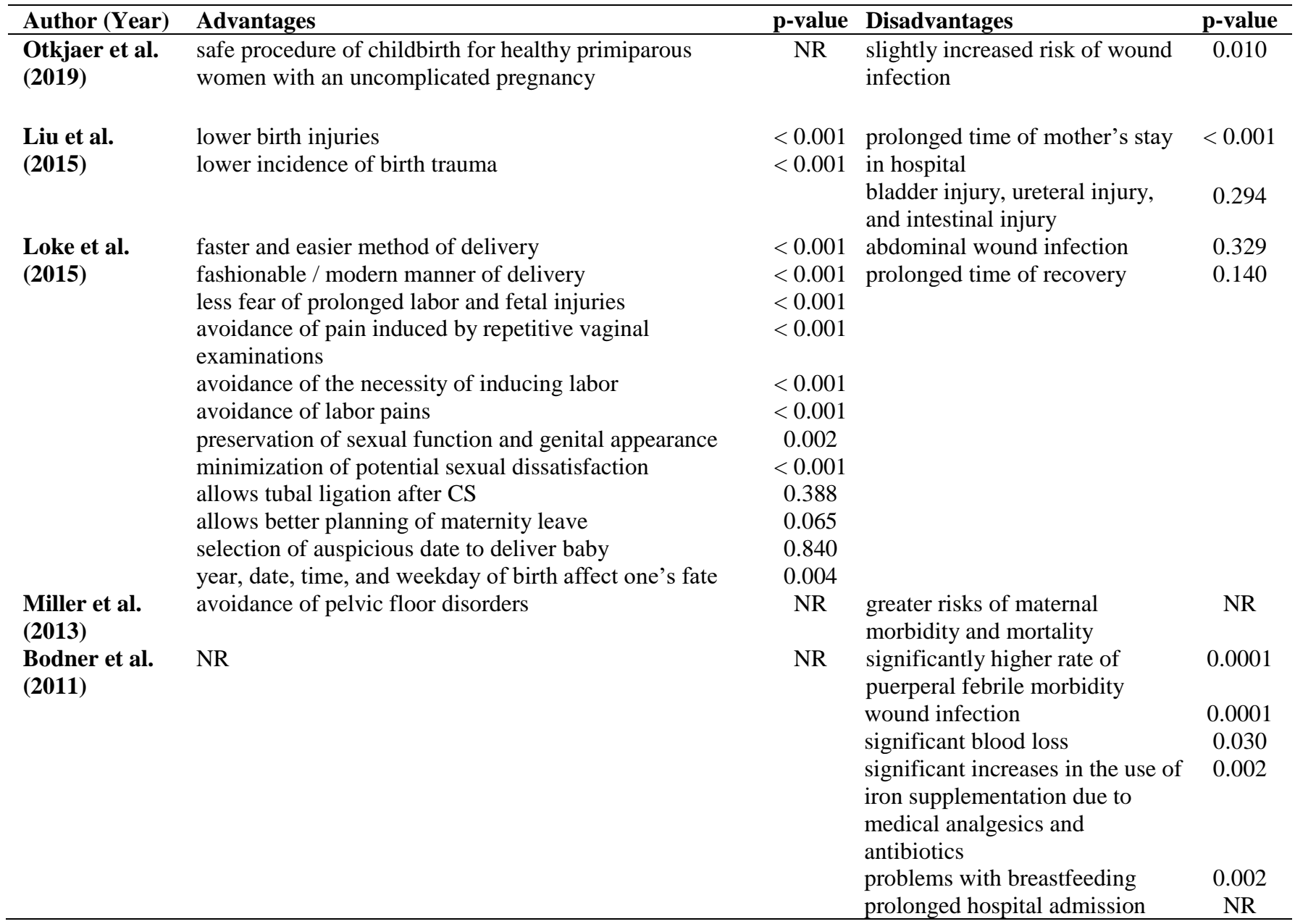


Table 3 Advantages and disadvantages of CSMR (Part 2)

\begin{tabular}{|c|c|c|c|c|}
\hline Author (Year) & Advantages & p-value & Disadvantages & p-value \\
\hline $\begin{array}{l}\text { Karlstörm et al. } \\
\text { (2011) }\end{array}$ & NR & NR & $\begin{array}{l}\text { a more negative birth } \\
\text { experience }\end{array}$ & $\mathrm{NR}$ \\
\hline \multirow{6}{*}{$\begin{array}{l}\text { Fenwick et al. } \\
\text { (2010) }\end{array}$} & guaranteed safety of CS & NR & higher level of anesthetic blocks & NR \\
\hline & higher level of "control" over the birth & NR & epidural complications & NR \\
\hline & & & wound infection & NR \\
\hline & alleviation of fear & NR & severe vomiting & NR \\
\hline & & & $\begin{array}{l}\text { sense of anticlimax was } \\
\text { unexpected and a little } \\
\text { disconcerting }\end{array}$ & NR \\
\hline & & & bleeding & NR \\
\hline
\end{tabular}

CS-cesarean section; $N R-$ not reported

Table 4 Neonatal reasons for choice of elective CSMR without indication

\begin{tabular}{|c|c|c|c|}
\hline Author (Year) & Reasons & Advantages & Disadvantages \\
\hline $\begin{array}{l}\text { Otkjaer et al. } \\
\text { (2019) }\end{array}$ & NR & NR & low birthweight \\
\hline $\begin{array}{l}\text { Liu et al. } \\
(2015)\end{array}$ & birth injury & $\begin{array}{l}\text { lower incidence of birth injury } \\
\text { lower incidence of infant infection } \\
\text { less likely to experience } \\
\text { complications with mild PPH }\end{array}$ & $\begin{array}{l}\text { increased risks of NICU admission } \\
\text { higher risk of respiratory distress } \\
\text { syndrome } \\
\text { frequency of NICU admission with } \\
\text { neonatal infection hypoxic ischemic } \\
\text { encephalopathy and meconium } \\
\text { aspiration syndrome } \\
\text { temporary facial nerve injury } \\
\text { associated with the use of short-arm } \\
\text { Simpson forceps and intraventricular } \\
\text { hemorrhage }\end{array}$ \\
\hline $\begin{array}{l}\text { Loke et al. } \\
(2015)\end{array}$ & $\begin{array}{l}\text { health of the baby } \\
\text { safer mode of birth for the neonate } \\
\text { concern for the health of the } \\
\text { newborn } \\
\text { worry about potential birth trauma } \\
\text { and respiratory trauma } \\
\text { to avoid fetal injuries }\end{array}$ & NR & NR \\
\hline $\begin{array}{l}\text { Sharpe et al. } \\
\text { (2015) }\end{array}$ & $\begin{array}{l}\text { concern for the baby's safety } \\
\text { welfare of the child }\end{array}$ & NR & NR \\
\hline $\begin{array}{l}\text { Miller et al. } \\
(2013)\end{array}$ & NR & $\begin{array}{l}\text { lower incidence of common cerebral } \\
\text { palsy and brachial plexus palsy and } \\
\text { neonatal morbidity } \\
\text { to avoid infrequent intrapartum } \\
\text { neonatal events due to long term } \\
\text { neurodevelopmental impairment }\end{array}$ & NR \\
\hline $\begin{array}{l}\text { Okonkwo et al. } \\
(\mathbf{2 0 1 2})\end{array}$ & ear of losing the baby during labor & NR & NR \\
\hline $\begin{array}{l}\text { Karlström et al. } \\
\text { (2011) }\end{array}$ & $\begin{array}{l}\text { great anxiety about threat to the } \\
\text { baby's life }\end{array}$ & NR & NR \\
\hline $\begin{array}{l}\text { Fenwick et al. } \\
\text { (2010) }\end{array}$ & $\begin{array}{l}\text { children of family or friends that } \\
\text { suffered some physical trauma as a } \\
\text { result of VD fear of physical injury } \\
\text { to baby }\end{array}$ & NR & fetal respiratory distress \\
\hline $\begin{array}{l}\text { Kingdon et al. } \\
(2009)\end{array}$ & allows choice of date of childbirth & NR & NR \\
\hline
\end{tabular}

$N I C U$ - neonatal intensive care unit; $N R$ - not reported; $P P H$ - primary pulmonary hypertension; $V D$ - vaginal delivery 


\section{Discussion}

There has been a global rise in CS over recent decades, with CSMR as the most important determinant of this increase in many countries. A cesarean section is a surgical procedure which can lead to several complications in both the mother and the baby, and accordingly, the World Health Organization emphasizes that CS should be carried out only when it is clearly advantageous (Otkjær et al., 2019). The risks of CSMR are higher than its benefits, but some obstetricians and gynecologists still perform elective CS on maternal request, which is of a great concern. The different attitudes to CSMR in gynecologists can be partly explained by the various cultural and social differences existing within countries (Sun et al., 2020). In the present systematic review, 16 studies examining the reasons for CS on maternal request, and the advantages and disadvantages of CSMR were analyzed. Fear of childbirth and its associated complications was the most common reason for CSMR. In line with our current findings, fear of VD was the most frequently cited psychological factor for CSMR (Alimohammadzade et al., 2013). Advanced maternal age, investigated in eight studies, was the second most frequent reason for CSMR. Today, in many developed countries, women give birth during their fourth decade of life due to social, economic, and educational factors; therefore, the rate of infertility, the use of assisted reproductive technologies, and the incidence of chronic diseases such as hypertension and diabetes are increasing in these women. Women aged 35 years or older are more likely to have delivery by CS (Benli et al., 2015). It is not increasing maternal age alone that is affecting the rate of CS, but the birth complications associated with advancing maternal age (Mylonas \& Friese, 2015).

In this study, birth experiences of family members, relatives, or friends were the most common social maternal reasons for elective CS. In a study conducted by Stoll et al. (2017), fear of childbirth can lead to CSMR. Consultation with experts, and the dissemination of positive accounts of women's experiences of childbirth can increase maternal awareness and reduce the rate of CS (Stoll et al., 2017). Some pregnant women choose CS due to concerns about risks for the infant. Evidence from the present study suggested that women were more likely to choose CS due to fear of physical injury to the baby during VD; yet several studies have shown that CS is associated with greater neonatal risks. Vidic et al. (2016) have demonstrated that Infants born at a lower gestational age exhibit a greater rate of Apgar scores, hypoglycemia, hyperbilirubinemia, respiratory distress syndrome, and neonatal intensive care admissions (Vidic et al., 2016). A review study has also shown elective CS to be associated with higher neonatal risks, such as respiratory morbidity, brachial plexus injury, sepsis, intracranial hemorrhage, asphyxia, encephalopathy, and death (Signore \& Klebanoff, 2008). In the present study, avoidance of labor pain, and a faster and easier method of delivery were the most common reasons for CSMR. The results of the current study are consistent with those of the study by Ecker and Frigolleto (2007) regarding the benefits associated with CS: greater degree of convenience for patient and obstetrician; decrease in complications, such as uterine rupture, reduced adverse perinatal outcomes e.g., hypoxic ischemic encephalopathy; and a reduction in complications associated with the use of vacuum and forceps, such as severe perineal laceration, urinary incontinence, and neonatal injuries (Ecker \& Frigoletto, 2007). In the present review, four studies indicated that wound infection was the most common maternal complication following CS, and two studies found that respiratory distress syndrome was the most common neonatal complication. Wound infection and hematoma occurred in 3\% of women following cesarean delivery, and this rate increased as the prevalence of maternal obesity or diabetes increased (Ecker \& Frigoletto, 2007). A review examining the maternal and fetal complications of emergency cesarean sections and elective CS reported that there was a higher risk of maternal complications, such as wound infection following emergency CS (Yang $\&$ Sun, 2017). Prevalence of these complications is aggravated by maternal conditions before or during pregnancy, meaning that older mothers, obese mothers, or those with chronic diseases are at increased risk of complications following CS (Leonard et al., 2019). A study comparing the maternal and neonatal consequences of elective CS with those of planned vaginal delivery (PVD) found that a considerably higher rate of puerperal febrile morbidity, wound infection, and significant blood loss were observed in the elective CS group, as well as problems with breastfeeding in the postpartum period, while neonatal outcomes were low in both groups, with no significant differences detected (Bodner et al., 2011). Currently, there are various health programs and approaches around the world which can increase mothers' awareness and change their attitudes towards VD. Knowledge of the benefits and disadvantages of CS and vaginal delivery should allow mothers to freely decide on the most suitable delivery method. Nevertheless, in spite of all these efforts, the prevalence of CS continues to increase worldwide. 


\section{Conclusion}

Fear of childbirth can be caused by ignorance or negative accounts of VD from other women, friends, relatives, family members, or mass media, and is the most frequent reason for CSMR. It should be understood that childbirth is a frightening event for the pregnant mother. Approaches that build confidence in mothers will help them overcome their fears. A comprehensive multilateral health plan put forward in collaboration with influential organs of society (such as the mass media) that increases positive cultural norms, changes women's opinions and attitudes towards VD, and increases their awareness and confidence so that they can dismiss negative accounts of VD from other women, friends, relatives, or family members can play a positive role in promoting VD and reducing maternal and neonatal mortality and morbidity. Clearly, if women have no indications for CS, VD is the best mode of delivery. In choosing the method of delivery, the advantages and disadvantages of each method should always be considered. In addition, the development of ways to reduce the pain of VD such as use of aromatherapy, water birth, and physiological delivery, and their promotion in women of reproductive age can help reduce the number of CSMRs without indication.

\section{Limitation of study}

The limitations of this review were as follows: limited access to information on maternal and neonatal mortality and morbidity in most hospital-based studies, the difficulty in predicting outcomes especially in women who experienced VD and were discharged from hospital sooner than those with CS, and women who had scheduled CS for breech birth (the rates of all neonatal complications in breech presentation were higher than in those in cephalic presentation), and, finally, the small number of certain articles, which made generalization difficult.

\section{Ethical aspects and conflict of interest}

This study has the code of ethics number IR.ABZUMS.REC.1398.193 from Alborz University of Medical Sciences. The authors declare no potential conflicts of interest.

\section{Acknowledgements}

The authors would like to thank Alborz University of Medical Science, Karaj, Iran.

\section{Author contributions}

FA and NSH fulfilled an advisory role. The remaining authors each contributed equally.

\section{References}

Abdi, F., Ozgoli, G., \& Rahnemaie, F. S. (2019). A systematic review of the role of vitamin $\mathrm{D}$ and calcium in premenstrual syndrome. Obstetrics \& Gynecology Science, 62(2), 73-86. https://doi.org/10.5468/ogs.2019.62.2.73

Akintayo, A. A., Ade-Ojo, I. P., Olagbuji, B. N., AkinAkintayo, O. O., Ogundare, O. R., \& Olofinbiyi, B. A. (2014). Cesarean section on maternal request: the viewpoint of expectant women. Archives of Gynecology and Obstetrics, 289, 781-785. https://doi.org/10.1007/s00404-013-3063-X

Alimohammadzade, K., Mohebi, S., \& Labaf, T. (2013). Systematic review of research papers in the recent three decades on the "reasons for cesarean section" and population health management strategies in Iran. Women's Strategic Studies (Ketabe Zanan), 61(16), 7-57.

Alsayegh, E., Bos, H., Campbell, K., \& Barrett, J. (2018). No. 361-Caesarean delivery on maternal request. Journal of Obstetrics and Gynaecology Canada, 40(7), 967-971. https://doi.org/10.1016/j.jogc.2017.12.009

American College of Obstetricians and Gynecologists. (2013). ACOG committee opinion no. 559: Cesarean delivery on maternal request. Obstetrics and Gynecology, 121(4), 904907. https://doi.org/10.1097/01.AOG.0000428647.67925.d3

Benli, A. R., Benli, N. C., Usta, A. T., Atakul, T., \& Koroglu, M. (2015). Effect of maternal age on pregnancy outcome and cesarean delivery rate. Journal of Clinical Medicine Research, 7(2), 97-102. http://dx.doi.org/10.14740/jocmr1904w

Blustein, J., \& Liu, J. (2015). Time to consider the risks of caesarean delivery for long term child health. BMJ, 350, h2410. https://doi.org/10.1136/bmj.h2410

Bodner, K., Wierrani, F., Grünberger, W., \& Bodner-Adler, B. (2011). Influence of the mode of delivery on maternal and neonatal outcomes: a comparison between elective cesarean section and planned vaginal delivery in a low-risk obstetric population. Archives of Gynecology and Obstetrics, 283, 1193-1198. https://doi.org/10.1007/s00404-010-1525-y

Câmara, R., Burlá, M., Ferrari, J., Lima, L., Amim Junior. J., Braga, A., \& Rezende Filho, J. (2016). Cesarean section by maternal request. Revista do Colégio Brasileiro de Cirurgiões, 43(4), 301-310. https://doi.org/10.1590/0100$\underline{69912016004002}$

Carter, M. (2016). Maternal and neonatal outcomes for cesarean delivery at maternal request (CDMR) during hospital stay: a quantitative study. Theses in Nursing. California State University San Marcos, 8-41.

Ecker, J. L., \& Frigoletto Jr, F. D. (2007). Cesarean delivery and the risk-benefit calculus. The New England Journal of Medicine, 356, 885-888.

https://doi.org/10.1056/NEJMp068290

Fenwick, J., Staff, L., Gamble, J., Creedy, D. K., \& Bayes, S. (2010). Why do women request caesarean section in a normal, healthy first pregnancy? Midwifery, 26(4), 394-400. https://doi.org/10.1016/j.midw.2008.10.011

Gao, Y., Tang, Y., Tong, M., Du, Y., \& Chen, Q. (2019). Does attendance of a prenatal education course reduce rates of caesarean section on maternal request? A questionnaire study in a tertiary women hospital in Shanghai, China. BMJ Open, 9(6), e029437. http://dx.doi.org/10.1136/bmjopen-2019$\underline{029437}$

Handelzalts, J. E., Fisher, S., Lurie, S., Shalev, A., Golan, A., \& Sadan, O. (2012). Personality, fear of childbirth and cesarean delivery on demand. Acta Obstetricia et 
Gynecologica Scandinavica, 91(1), 16-21.

Karlström, A., Nystedt, A., \& Hildingsson, I. (2011). A comparative study of the experience of childbirth between women who preferred and had a caesarean section and women who preferred and had a vaginal birth. Sexual \& Reproductive Healthcare, 2(3), 93-99.

https://doi.org/10.1016/j.srhc.2011.03.002

Kingdon, C., Neilson, J., Singleton, V., Gyte, G., Hart, A., Gabbay, M., \& Lavender, T. (2009). Choice and birth method: mixed-method study of caesarean delivery for maternal request. BJOG: An International Journal of Obstetrics \& Gynaecology, 116(7), 886-895.

Kringeland, T., Daltveit, A. K., \& Møller, A. (2009). What characterizes women in Norway who wish to have a caesarean section? Scandinavian Journal of Public Health, 37(4), 364-371. https://doi.org/10.1177/1403494809105027

Leonard, S. A., Main, E. K., \& Carmichael, S. L. (2019). The contribution of maternal characteristics and cesarean delivery to an increasing trend of severe maternal morbidity. BMC Pregnancy and Childbirth, 19, 16. https://doi.org/10.1186/s12884-018-2169-3

Liu, X., Landon, M. B., Cheng, W., \& Chen, Y. (2015). Cesarean delivery on maternal request in China: what are the risks and benefits? American Journal of Obstetrics and Gynecology, 212(6), 817E1-817E9. https://doi.org/10.1016/j.ajog.2015.01.043

Loke, A. Y., Davies, L., \& Li, S.-f. (2015). Factors influencing the decision that women make on their mode of delivery: the Health Belief Model. BMC Health Services Research, 15, 274. https://doi.org/10.1186/s12913-015-0931-z

Miller, E. S., Hahn, K., Grobman, W. A. (2013). Consequences of a primary elective cesarean delivery across the reproductive life. Obstetrics \& Gynecology, 121(4), 789797.

https://doi.org/10.1097/AOG.0b013e3182878b43

Munro, S., Kornelsen, J., \& Hutton, E. (2009). Decision making in patient-initiated elective cesarean delivery: the influence of birth stories. Journal of Midwifery \& Women's Health, 54(5), 373-379.

Mylonas, I., \& Friese, K. (2015). Indications for and risks of elective cesarean section. Deutsches Ärzteblatt International, 112, 489-495. https://doi.org/10.3238/arztebl.2015.0489

Navaee, M., \& Abedian, Z. (2015). Effect of role play education on primiparous women's fear of natural delivery and their decision on the mode of delivery. Iranian Journal of Nursing and Midwifery Research, 20(1), 40-46.

Okonkwo, Ojengbede, O. A., Morhason-Bello, I. O., \& Adedokun, B. O. (2012). Maternal demand for cesarean section: perception and willingness to request by Nigerian antenatal clients. International Journal of Women's Health, 4, 141-148. https://doi.org/10.2147/IJWH.S10325

Olieman, R. M., Siemonsma, F., Bartens, M. A., GarthusNiegel, S., Scheele, F., \& Honig, A. (2017). The effect of an elective cesarean section on maternal request on peripartum anxiety and depression in women with childbirth fear: a systematic review. BMC Pregnancy and Childbirth, 17, 195. https://doi.org/10.1186/s12884-017-1371-z

Otkjær, A. M., Jørgensen, H. L., Clausen, T. D., \& Krebs, L. (2019). Maternal short-term complications after planned cesarean delivery without medical indication: a registry based study. Acta Obstetricia et Gynecologica Scandinavica, 98(7), 905-912. https://doi.org/10.1111/aogs.13549

Rahnemaie, F. S., Zare, E., Zaheri, F., \& Abdi, F. (2019). Effects of complementary medicine on successful breastfeeding and its associated issues in the postpartum period. Iranian Journal of Pediatrics, 29(1), e80180. https://doi.org/10.5812/ijp.80180

Sharpe, A. N., Waring, G. J., Rees, J., McGarry, K., \& Hinshaw, K. (2015). Caesarean section at maternal request the differing views of patients and healthcare professionals: a questionnaire based study. European Journal of Obstetrics \& Gynecology and Reproductive Biology, 192, 54-60.

https://doi.org/10.1016/j.ejogrb.2015.06.014

Signore, C., \& Klebanoff, M. (2008). Neonatal morbidity and mortality after elective cesarean delivery. Clinics in Perinatology, 35(2), 361-371.

https://doi.org/10.1016/j.clp.2008.03.009

Stoll, K. H., Hauck, Y. L., Downe, S., Payne, D., Hall, W. A. \& International Childbirth Attitudes - Prior to Pregnancy (ICAPP) Study Team. (2017). Preference for cesarean section in young nulligravid women in eight OECD countries and implications for reproductive health education. Reproductive Health, 14, 116. https://doi.org/10.1186/s12978-017-0354-X

Sun, N., Yin, X., Qiu, L., Yang, Q., \& Gong, Y. (2020). Chinese obstetricians' attitudes, beliefs, and clinical practices related to cesarean delivery on maternal request. Women and Birth, 33(1), e67-e71. https://doi.org/10.1016/j.wombi.2019.03.001

Sydsjö, G., Möller, L., Lilliecreutz, C., Bladh, M., Andolf, E., \& Josefsson, A. (2015). Psychiatric illness in women requesting caesarean section. BJOG: An International Journal of Obstetrics \& Gynaecology, 122(3), 351-358. https://doi.org/10.1111/1471-0528.12714

Vidic, Z., Blickstein, I., Štucin Gantar, I., Verdenik, I., \& Tul, N. (2016). Timing of elective cesarean section and neonatal morbidity: a population-based study. The Journal of Maternal-Fetal \& Neonatal Medicine, 29(15), 2460-2462. https://doi.org/10.3109/14767058.2015.1087500

Yang, X.-J., \& Sun, S.-S. (2017). Comparison of maternal and fetal complications in elective and emergency cesarean section: a systematic review and meta-analysis. Archives of Gynecology and Obstetrics, 296, 503-512. https://doi.org/10.1007/s00404-017-4445-2

Zamani-Alavijeh, F., Araban, M., Hassanzadeh, A., \& Makhouli, K. (2018). Contributing factors of pregnant women's beliefs towards mode of delivery: a cross-sectional study from Iran. Maternal Health Neonatology and Perinatology, 4, 9. https://doi.org/10.1186/s40748-018$\underline{0077-1}$ 